\title{
DIGITALIZATION - SUSTAINABLE DEVELOPMENT CONVERGENCE: METRICS AND EFFECTS IN ROMANIA
}

\author{
Sebastian Emanuel Stan ${ }^{1}$, Camelia Oprean-Stan ${ }^{2}$, Aurel Mihail Țîtu ${ }^{3}$ \\ ${ }^{1}$ Land Forces Academy Nicolae Balcescu, Sibiu, Romania, sebastian.stan@armyacademy.ro \\ ${ }^{2}$ Lucian Blaga University of Sibiu, 10, Victoriei Street, Sibiu, România, camelia.oprean@ulbsibiu.ro \\ ${ }^{3}$ Lucian Blaga University of Sibiu, 10, Victoriei Street, Sibiu, România, The Academy of Romanian Scientists, 54, Splaiul \\ Independenței, Sector 5, Bucharest, Romania, mihail.titu@ulbsibiu.ro
}

\begin{abstract}
Sustainability and digitalization both require major transitions in our world and the way we imagine them. Digitalization is considered to be the engine that alters sustainability. However, it is not yet known whether and to what extent this digital transformation facilitates or hinders the development of a more sustainable world. The aim of this paper is to shed light on the implications of digitalization for sustainable development in Romania and to provide answers to the following questions: how does digitalization affect the most important pillars of sustainability? How can digital technology help to achieve the Sustainable Development Goals in the next period? These key issues are of immediate practical relevance and therefore need to be addressed by researchers and decision-makers alike. In order to achieve this objective, this research examines the relationship between digitalization and sustainable development, in the specific case of Romania, and examines how digital performance affects the main components of sustainable development, pursued on the basis of the following sustainable development objectives: non-poverty, good health and well-being, gender equality, decent work and economic growth, At the same time, it examines the most important measures for evaluating the level of digitalization of countries (more specifically, the Digital Economy and Society Index DESI methodology) and sustainable development at the macro-economic level (through the Sustainable Development Goals Index SDGI components).
\end{abstract}

KEY WORDS: digitalization, sustainability, sustainable development goals

\section{INTRODUCTION}

Permanent innovation through the creative capacity of the individual-in all fields-is equivalent to implicit progress. The economic-technological systems, which began with the type of agricultural production, have evolved enormously so far. In the last half of the last century, a trend of increased economic growth could be identified as a result of the digital revolution and the exploitation of knowledge as a distinct resource. We are in a period of accelerated transition to new economic and social models, which no longer leaves room for barriers between systems, leading to complex and profound transformations in all areas of activity, in organizations, markets and public institutions. Constant economic, social and technological changes and competitive advantages mean a permanent need to restructure and improve the knowledge management system, which is seen as a defining factor in economic growth. In this context, the efficient management of the newly accepted intangible factors of production becomes essential in the new economy, both at the micro and macro levels. Knowledge is a new resource, the true capital of modern economies.

In this context, changes are taking place within companies and organizations in the following areas: orientation towards a lower complexity of activities, flexible structures, small dimensions of tangible assets, through which the organization can quickly adapt to contextual developments; the culture of the organization must promote and support the innovation process on a continuous basis; competitiveness through innovation is becoming a rule, with the capacity to generate innovations; changing investment priorities that are geared towards investment in human resources; very large investments for the endowment of state-of-the-art information technologies; investment in technology and robotics; allocation of funds to ensure knowledge security.

Digitalization promise - big data, artificial intelligence, internet, cybersecurity - is sometimes defined with hyperbole. Both analysts and academics have identified "big data" as the primary catalyst of a management and technology revolution, the fourth industrial revolution and the second computer era.

Sustainability is the 21 st century 's main moral and economic imperative, and is one of the most important sources of opportunities and risks for companies. Nature, society and business are interconnected in complex ways which decisionmakers should understand. Many of the world's most prominent organizations actively advocate sustainable growth, with many focused-on attempts to achieve the UN's sustainable development goals.

In this context, the digitalization-sustainability convergence in business and society provides both opportunities and challenges to executives, within the enterprise and across corporate borders. Digital tools are used by businesses to map their environmental footprint and determine the effect of environmental changes on their company. New digital innovations are promoting sustainable innovation, but they introduce new vulnerabilities such as cybercrime and loss of privacy.

The digitalization-sustainability convergence is creating, outside the enterprise, a digital revolution in three areas that affect market conditions: investor behaviour, urbanization and economic demand.

Digital technologies in the form of electronic financial or health services, robotics or emission reduction solutions could help individuals, organizations and nations to achieve a more sustainable planet in the light of sustainable development goals. In view of the stage of sustainable development, differences 
between states remain a major problem, as the overappropriation of natural resources and their harmful consequences threaten the basis of our existence and future generations (WCED, 1987).

Digitalization has an incalculable potential to contribute to the sustainability of the planetary and human systems, or at least to help reduce the negative impact of humans. Many authors (such as Gijzen, 2013), Hampton et al., 2013) state in their specialized studies that ICT and Big Data can help to promote sustainability.

Sustainability and digitalization both require major transitions in our world and the way we imagine them. In this sense, sustainability science is the scientific way to gather data to analyze ways to a (more) sustainable world, taking into account future generations. Due to its transformative nature, sustainability will adapt to the new possibilities and dangers of the digital age, or vice versa, digitalization is the driving force behind sustainability. However, it is not yet known whether and to what extent this digital transformation facilitates or hinders the development of a more sustainable world.

The aim of this paper is to shed light on the implications of digitalization for sustainable development in Romania and to provide answers to the following questions: how does digitalization affect the most important pillars of sustainability? How can digital technology help to achieve the $17 \mathrm{UN}$ Sustainable Development Goals in the next period? These key issues are of immediate practical relevance and therefore need to be addressed by researchers and decision-makers alike. In order to achieve this objective, this research examines the relationship between digitalization and sustainable development, in the specific case of Romania, and examines how digital performance affects the main components of sustainable development, pursued on the basis of the following sustainable development objectives: non-poverty, good health and well-being, gender equality, decent work and economic growth, sustainable cities and communities, peace, justice and strong institutions. The basis of this research is the following research question: if and to what extent does the digital transformation affect the objectives of sustainable development in Romania and its components? At the same time, it examines the most important measures for evaluating the digitalization of countries (more specifically, the Digital Economy and Society Index DESI methodology) and sustainable development at the macro-economic level (through the Sustainable Development Goals Index SDGI components).

The remainder of this article is structured as follows: Section 2 presents conceptual approaches and a literature review explains critical concepts such as digitalization and sustainable development. This section also discusses the methodology of the main indicator used to measure the level of digitalization in a country and highlights the situation of Romania with regard to the level of digitalization. The research methodology is presented in the third part and also here the empiric results are mentioned and discussed. The findings of the study are outlined in the final part of the article.

\section{CONCEPTUAL APPROACHES TO DIGITALIZATION AND SUSTAINABLE DEVELOPMENT}

Today's society is increasingly focusing on a number of relevant factors that should be taken into account by researchers and decision-makers alike. These factors can be identified as digital transformation, sustainability and innovation.
We are discovering digital technology, in particular its speed and its increasing spread across all areas of life. According to Schmidt and Cohen (2013), information and communications (ICT) technology is our new digital age, which includes a wealth of software, hardware and related processes. Chronologically speaking, we are living in the third era of digital transformation, with new challenges facing governments, companies, entrepreneurs and customers (Schwab, 2016). Schmarzo (2017) points out that this era of digital transformation is the "application of digital capabilities to processes, products and assets", all with the aim of "improving efficiency, increasing customer value, managing risks and discovering new opportunities for monetization". In the same way, others (Bertini, 2016; Jovanovic, 2018) point out that digital transformation affects not only life but also individual experiences.

Digital, through recordings, online, social media profiles and much more (Boyd and Crawford, 2012) have changed the way people interact with each other and in relation to their natural environment. Digital technology, as in the case of Big Data, offers new opportunities and ways to shape the future and innovations (Shah et al., 2015). By implementing smart technologies in all systems, it is possible to have a significant impact on the quality of life on our planet.

Digitalization is a phenomenon of uninterrupted expansion, which is becoming an indispensable part of today's society. Financial institutions are engaged in a process of renewal as a result of digitalization. However, the specific details of these radical changes should not be overlooked. Moreover, digitalization does not only mean the introduction of innovative technologies, but there are major changes in financial systems and, moreover, in the organizational culture of any institution.

The digital economy can develop intensely in the context of the current crisis caused by Covid-19, as society avoids congestion and prefers to solve problems from the comfort of its own home. Thus, the challenge is to adapt to new customer requirements. Digital variants must be cheap, easy to use, even for people without technical knowledge, but also to solve a large part of the customer requests. In this sense, a broad analysis is needed, as the effects of Covid-19 are not only observed at the health level, but are also very strongly felt in all spheres of economic activity.

In order to measure the level of digitalization achieved in a country, the European Commission has developed the Digital Economy and Society Index (DESI), a composite measure that summarizes indicators related to the digital performance and digital competitiveness of EU Member States. According to DESI, there has been a significant development in information, communications and digital systems in recent years.

It is composed of a set of indicators related to the digital policy mix and has a three-tier structure (European Commission, 2020). At the first level there are five main dimensions: connectivity, human capital, Internet use, digital technology integration and digital public services. At the second level there are 12 indicators and at the third level there are 37 individual indicators. The structure of the DESI, but also of the 5 main dimensions, with the weighting system is shown in Figure 1. Given the weighting system used to calculate the final DESI score, not all dimensions have the same weight: connectivity and human capital have the greatest impact of $25 \%$ each, followed by the integration of digital technology by $20 \%$, while the use of the Internet and digital public services have the least impact of $15 \%$. The subdimensions also have a different weighting system shown in Figure 1. The digital development of the economy and society 
can only be achieved through the interlinked development of these areas (European Commission, 2020).

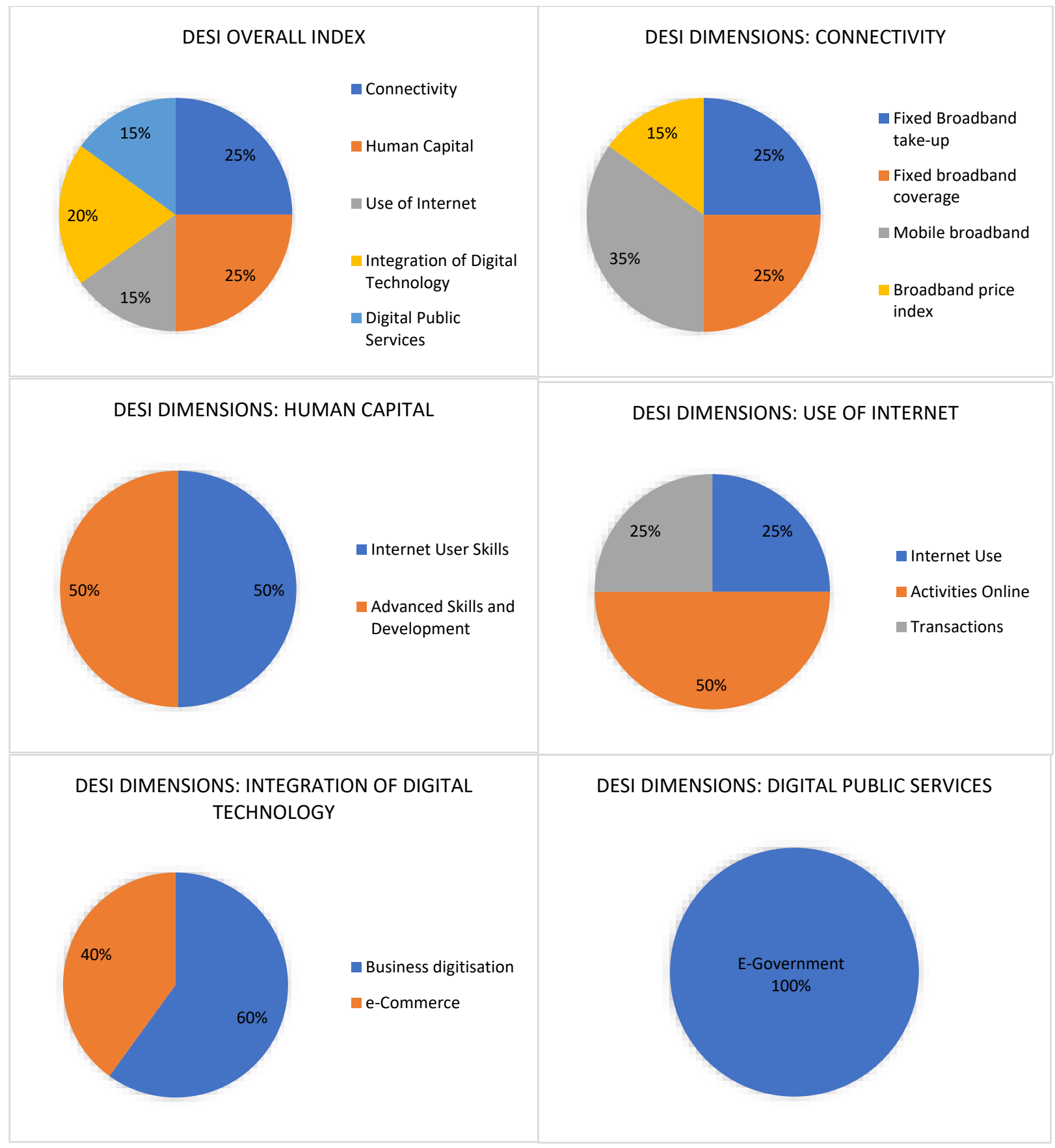

Figure 1. The structure and main dimensions of the Digital Economy and Society Index (DESI).

Source: adapted from European Commission

From the point of view of the digital economy and society, according to the ranking published by the European Commission in 2020 (presented in Figure 2), Romania occupies a marginal position in most of the indicators that make up the DESI (Digital Economy and Society Index) composite index.

Progress compared to previous years is slow, below the actual potential. Romania continues to face significant deficiencies in the development of society, the economy, education and digital services compared to the average of EU Member States. All of this directly translates into a low level of competitiveness and attractiveness for the digital economy in Romania, with considerable differences, including internally, between regions and rural and urban environments. In particular, Romania ranks 26th out of 28 EU Member States in the Digital Economy and Society Index (DESI) for 2020. Based on pre-pandemic data, the performance of Romania was identical in four of the five DESI dimensions measured. Romania has the best connectivity performance due to the high use of very high-speed broadband and the wide availability of very high capacity fixed networks, particularly in urban areas. 49 per cent of households in Romania are subscribed to very high-speed broadband services (at least $100 \mathrm{Mbps}$ ), making Romania ranked 5th in the EU. However, the digitalization of the economy has lagged behind, given that almost a fifth of Romanians have never used the Internet, and less than a third have at least basic digital skills. Romania is well-positioned in terms of ICT graduates, ranking fifth, with 5.6 per cent of all graduates (EU average: 3.6 per cent); however, in terms of digital public services and the use of internet services, Romania's performance is the lowest among EU Member States. 


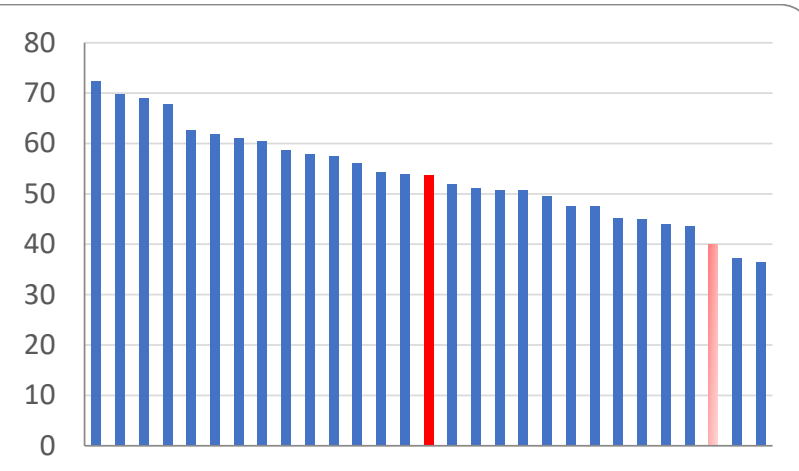

FI DK MT EE BE ES AT EU SI LV HR SK CY RO BG

Figure 2. Digital Economy and Society Index (DESI) 2020 ranking.

\section{Source: European Commission}

Since the 1980s, sustainability has been a common subject and an extensively debated subject in scientific literature, both conceptually and empirically (Ahi et al., 2018; Cantele and Zardini, 2018; Hussain et al., 2018; Tseng et al., 2018), and is still under consideration due to its different dimensions (Ordieres-Meré, 2020). Researchers have demonstrated the importance of sustainability at all conceivable levels, including corporate level (Ababneh and Aga, 2019; Boros and Fogarassy, 2019; Nielsen, 2018; Oprean-Stan et al., 2020), as well as national and global levels (Clayton and Radcliffe, 2015; Drexhage and Murphy, 2015). Sustainability is often seen as a central component of individuals, organisations and governments' policies. In this context, the way we adapt to the norms of a globalized world, the threats we face in the future, and the changing developments in technology and goods are all an important part of sustainability.

Dang and Pheng (2015) explored new theories of economic development and noted that with a view to achieving rapid economic growth, countries around the world are using their natural resource reserves at alarming rates. Both science and society have observed this reality and, as a result, sustainable development has increasingly been identified as a priority for nations and businesses. Sustainable development is a development that meets the needs of today, without compromising the ability of future generations to meet their own needs. This concept suggests that human well-being can only be achieved through the synergy of three basic pillars: economic growth, social equity and environmental protection (Jovanovic, 2018).

\section{METHODOLOGY AND RESEARCH DESIGN}

To examine objectively the relationship between the digitalization process and sustainable development, we have encountered difficulties in the fact that there are still no widely accepted methodologies for measuring the general concept of sustainability, but we have found methodologies that include one or more dimensions of sustainable development (e.g. Global Competitiveness Index, Global Innovation Index, Global Entrepreneurship Index, Good Country Index, etc.) (Jovanovic, 2018). The most complex measure we have identified to measure all aspects of sustainable development at national level is the Sustainable Development Goals Index (SDGI). This is the result of a global study that assesses how much each country contributes to the achievement of the Sustainable Development Goals. The Sustainable Development Solutions Network and
Bertelsmann Stiffung publish these reports annually with guides for leaders on how to identify priorities and track progress towards objectives.

The Sustainable Development Report (formerly the SDG Index \& Dashboards) is the first global analysis to determine the role of each nation in achieving the Sustainable Development Goals. Unlike its Millennium Development Goals counterpart, the SDGs set standards not only for emerging and developed countries, but also for the industrialized nations. The Sustainable Development Report can be used by governments and civil society alike to identify action goals, consider key policy issues, monitor progress, ensure transparency, and identify gaps that need to be filled to achieve the SDGs by 2030 .

The Sustainable Development Report 2020 (SDR2020) presents and aggregates data on country results towards the SDGs, as in previous years. It is not an official reporting tool for the SDG but rather complements efforts by national statistical offices and international organizations to collect data on and standardize SDG indicators. To this end, the SDR2020 provides the most upto - date data from official sources (UN, World Bank and others) as well as from non-official sources (research institutions and NGOs).

The SDG Index tracks the country performance of the 17 SDGs, as agreed by the international community in 2015, with equal weight for all 17 goals. Each objective is represented by between 3 and 17 indicators, using a total of 116 partial indicators. As in previous editions, Sweden, Denmark and Finland are the top three Nordic countries in the 2020 SDG Index (see Figure 3). Overall, the world has made progress towards the SDGs. Also, in the 2020 ranking, Romania is in a modest position, at the end of the ranking, along with two other countries, Greece and Bulgaria.

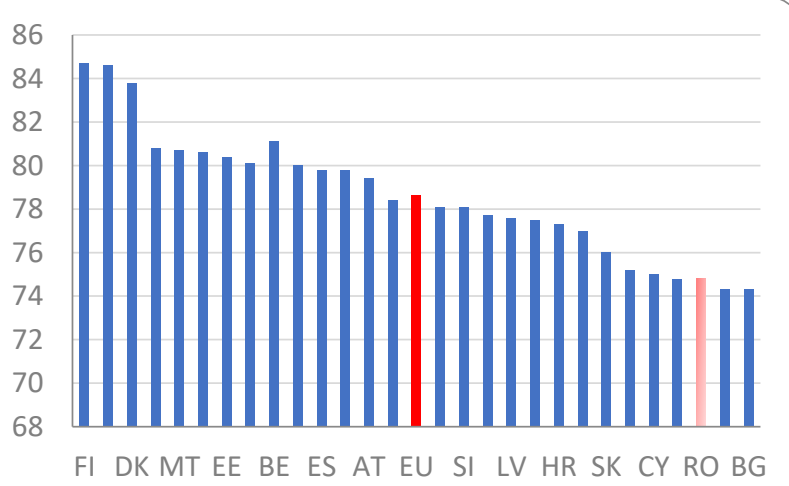

Figure 3. Performance of the Sustainable Development Goals (SDG) country index in 2020.

Source: adapted from Sustainable Development Report 2020

In this research, in the case of Romania, we measured the correlation between the DESI and the set of selected indicators, components of the Sustainable Development Goals Index, which measure certain aspects of sustainable development in this country. The description of these indicators taken into account, together with the objectives of sustainable development which they represent, is shown in Table 1. The argument for selecting only these indicators in the analysis is that, in Romania, these indicators provided data calculated for the period considered in the study (2015-2020) given that the data for the other indicators had not yet been calculated.

Table 1. Description of indicators for sustainable development considered in the study. 


\begin{tabular}{|c|c|c|}
\hline SDG & Indicator & Description \\
\hline $\begin{array}{c}\text { 1.no } \\
\text { poverty }\end{array}$ & $\begin{array}{l}\text { Poverty } \\
\text { headcount } \\
\text { ratio at } \\
\$ 1.90 / \text { day } \\
(\%)\end{array}$ & $\begin{array}{l}\text { Estimated percentage of } \\
\text { population living below the } \\
\text { US\$ } 1.90 \text { daily poverty level. } \\
\text { Estimated using historical } \\
\text { estimates of income } \\
\text { distribution, demographic } \\
\text { change projections by age } \\
\text { and educational } \\
\text { achievement, as well as GDP } \\
\text { projections. }\end{array}$ \\
\hline $\begin{array}{c}\text { 3.good } \\
\text { health and } \\
\text { well-being }\end{array}$ & $\begin{array}{l}\text { Subjective } \\
\text { well-being } \\
\text { (average } \\
\text { ladder score, } \\
\text { worst } 0-10 \\
\text { best) }\end{array}$ & $\begin{array}{l}\text { Subjective self-evaluation of } \\
\text { life, where respondents are } \\
\text { asked to decide where they } \\
\text { believe they are placed on a } \\
\text { ladder where } 0 \text { is the worst } \\
\text { life possible and } 10 \text { is the } \\
\text { best life possible. }\end{array}$ \\
\hline $\begin{array}{l}\text { 5.gender } \\
\text { equality }\end{array}$ & $\begin{array}{l}\text { Ratio of } \\
\text { female-to- } \\
\text { male labor } \\
\text { force } \\
\text { participation } \\
\text { rate }(\%)\end{array}$ & $\begin{array}{l}\text { Modeled estimate of the } \\
\text { proportion of the female } \\
\text { population aged } 15 \text { years and } \\
\text { older that is economically } \\
\text { active, divided by the same } \\
\text { proportion for men. }\end{array}$ \\
\hline $\begin{array}{l}\text { 8. decent } \\
\text { work and } \\
\text { economic } \\
\text { growth }\end{array}$ & $\begin{array}{l}\text { Unemployme } \\
\text { nt rate (\% of } \\
\text { total labor } \\
\text { force) }\end{array}$ & $\begin{array}{l}\text { Model estimation of the } \\
\text { labor force share, which is } \\
\text { available without work but is } \\
\text { actively pursuing jobs. The } \\
\text { measure represents an } \\
\text { economy's failure to create } \\
\text { jobs for people who want to } \\
\text { work but } \\
\text { don't. }\end{array}$ \\
\hline $\begin{array}{l}\text { 11.sustaina } \\
\text { ble cities } \\
\text { and } \\
\text { communiti } \\
\text { es }\end{array}$ & $\begin{array}{l}\text { Satisfaction } \\
\text { with public } \\
\text { transport }(\%)\end{array}$ & $\begin{array}{l}\text { The percentage of the } \\
\text { population surveyed who } \\
\text { replied "pleased" with the } \\
\text { question "Are you pleased or } \\
\text { unhappy with the public } \\
\text { transit systems in the city or } \\
\text { area in which you live?" }\end{array}$ \\
\hline \multirow{3}{*}{$\begin{array}{l}\text { 16.peace, } \\
\text { justice and } \\
\text { strong } \\
\text { institutions }\end{array}$} & $\begin{array}{c}\text { Percentage of } \\
\text { population } \\
\text { who feel safe } \\
\text { walking alone } \\
\text { at night in the } \\
\text { city or area } \\
\text { where they } \\
\text { live }(\%)\end{array}$ & $\begin{array}{l}\text { The percentage of the } \\
\text { population being surveyed } \\
\text { who replied "Yes" to the } \\
\text { question "Do you feel safe to } \\
\text { walk alone at night in the } \\
\text { city or area where you live?" }\end{array}$ \\
\hline & $\begin{array}{l}\text { Corruption } \\
\text { Perception } \\
\text { Index (worst } \\
0-100 \text { best) }\end{array}$ & $\begin{array}{c}\text { Perceived levels of } \\
\text { corruption in the public } \\
\text { sector, on a scale from } 0 \\
\text { (highest perceived corruption } \\
\text { level) to } 100 \text { (lowest } \\
\text { perceived corruption level). }\end{array}$ \\
\hline & $\begin{array}{c}\text { Press } \\
\text { Freedom } \\
\text { Index (best 0- } \\
100 \text { worst) }\end{array}$ & $\begin{array}{c}\text { Degree of freedom available } \\
\text { to journalists. }\end{array}$ \\
\hline
\end{tabular}

Source: adapted from Sustainable Development Goals Index 2020

\section{Empirical data and correlation analysis}

Because the methodologies considered in this study are relatively young (the European Commission started measuring DESI in 2014), the period considered in this study was 20152020, when data were available for Romania for both the digitalization measurement indicator and indicators for measuring sustainable development. Data were collected for Romania from 2015 to 2020 using the basic data provided by the European Commission for DESI and the Sustainable Development Solutions Network in partnership with BertelsmannStiftung for the calculation of the Sustainable Development Goals Index methodology.

We used the SPSS software to calculate the correlation analysis. Since the sample size was relatively small, the first step was to determine whether the data were normally distributed using the Shapiro-Wilk test (Table 2).

Table 2. Tests of Normality.

\begin{tabular}{|c|c|c|c|c|c|c|}
\hline & \multicolumn{3}{|c|}{$\begin{array}{l}\text { Kolmogorov- } \\
\text { Smirnov }^{\mathrm{a}}\end{array}$} & \multicolumn{3}{|c|}{ Shapiro-Wilk } \\
\hline & Statistic & df & Sig. & Statistic & df & Sig. \\
\hline DESI & .160 & 6 & $.200^{*}$ & .986 & 6 & .979 \\
\hline powerty ratio & .382 & 6 & .007 & .719 & 6 & .010 \\
\hline $\begin{array}{l}\text { subjective well- } \\
\text { beig }\end{array}$ & .262 & 6 & $.200^{*}$ & .855 & 6 & .174 \\
\hline $\begin{array}{l}\text { ratio of female- } \\
\text { to-male labor } \\
\text { force }\end{array}$ & .179 & 6 & $.200^{*}$ & .936 & 6 & .626 \\
\hline $\begin{array}{l}\text { unemployement } \\
\text { rate }\end{array}$ & .264 & 6 & $.200^{*}$ & .887 & 6 & .302 \\
\hline $\begin{array}{l}\text { satisfaction } \\
\text { with public } \\
\text { transport }\end{array}$ & .219 & 6 & $.200^{*}$ & .952 & 6 & .755 \\
\hline $\begin{array}{l}\text { population safe } \\
\text { walking alone }\end{array}$ & .175 & 6 & $.200^{*}$ & .932 & 6 & .598 \\
\hline $\begin{array}{l}\text { corruption } \\
\text { perception } \\
\text { index }\end{array}$ & .223 & 6 & $.200^{*}$ & .826 & 6 & .099 \\
\hline $\begin{array}{l}\text { press freedom } \\
\text { index }\end{array}$ & .239 & 6 & $.200^{*}$ & .929 & 6 & .576 \\
\hline
\end{tabular}

a. Lilliefors Significance Correction

*. This is a lower bound of the true significance.

\section{Source: authors' estimations, using SPSS software}

In Table 2, one can see that all variables are normally distributed, as assessed by Shapiro-Wilk's test ( $\mathrm{p}>.05)$.

A Pearson's product-moment correlation was run in SPSS Statistics to assess the relationship between the digitalization measure (DESI) and the sustainable development measures in Romania. The results are presented in Table 3.

The results show that most of the measures are significantly correlated with the DESI values. Subjective well-being, corruption perception index and population feeling safe walking alone have a strong positive relationship with DESI (from .577 to .907), which means that a high-digitalization country is more likely to provide its citizens with a sense of well-being in the way they live, because digital societies meet basic needs and provide better education. 
Table 3. Correlation Analysis .

\begin{tabular}{|ll|c|}
\hline & & DESI \\
\hline \multirow{2}{*}{ poverty ratio } & Pearson Correlation & -.424 \\
& Sig. (2-tailed) & .402 \\
\hline \multirow{2}{*}{ subjective well-being } & Pearson Correlation &. $\mathbf{9 0 7}$ \\
& Sig. (2-tailed) & .013 \\
\hline ratio of female-to-male & Pearson Correlation & -.531 \\
labor force & Sig. (2-tailed) & .278 \\
\hline \multirow{2}{*}{ unemployment rate } & Pearson Correlation & $\mathbf{- . 9 6 3}$ \\
& Sig. (2-tailed) & .002 \\
\hline satisfaction with public & Pearson Correlation & -.124 \\
transport & Sig. (2-tailed) & .816 \\
\hline population safe walking & Pearson Correlation & .577 \\
alone & Sig. (2-tailed) & .230 \\
\hline corruption perception & Pearson Correlation & .804 \\
index & Sig. (2-tailed) & .054 \\
\hline \multirow{2}{*}{ press freedom index } & Pearson Correlation & -.037 \\
& Sig. (2-tailed) & .945 \\
\hline
\end{tabular}

*. Correlation is significant at the 0.05 level (2-tailed).

**. Correlation is significant at the 0.01 level (2-tailed). Source: authors' estimations, using SPSS software

Strong, but negative, correlations are evident this time between DESI and gender equality and unemployment (with correlations from -.531 to -.963 ). The interesting result for Romania is that, as the degree of digitalization of the country increases, gender equality decreases, more specifically the proportion of females aged 15 years and older who are economically active, divided by the same proportion of males. But if digitalization increases, it will have the effect of massively lowering the unemployment rate, i.e. eliminating the inability of the economy to create employment for people who want to work but do not.

The Pearson correlation coefficient for poverty ratio $(r=-.424)$ suggests a medium strength, negative correlation, which indicates that, as the degree of digitalization in Romania progresses, this will work favorably towards a declining poverty ratio.

The results indicate a small negative correlation between DESI and public transport satisfaction $(\mathrm{r}=-.124)$, i.e. increasing digitalization implies a perception of citizens' dissatisfaction with public transport systems in the city or area where they live. The latest indicator on sustainable development, the press freedom index, does not appear to be affected in any way by the development of the degree of digitalisation in Romania.

\section{CONCLUSIONS}

Recently, sustainable development has been identified as a priority action in all nations. The question arises as follows: if and to what extent does the digital transformation affect the objectives of sustainable development?

To answer this question, we conducted research in which the degree of digitalization of Romania is compared with the components of the Sustainable Development Goals Index, as the sustainable development measures.

A Pearson's product-moment correlation was run to assess the relationship between the digitalization measure (DESI) and the sustainable development measures in Romania. Preliminary analyses showed the relationship to be linear with all variables normally distributed, as assessed by Shapiro-Wilk's test ( $\mathrm{p}>$ $.05)$, and there were no outliers.

The results show that digitalization is strongly linked to the components of sustainable development. Higher digitalization is associated with a strong relationship with subjective well-being, corruption perception index, and a population that feels safe to walk alone. There is a significant but negative link between digitalization and gender equality and the unemployment rate in Romania.

There was a statistically significant, strong positive correlation between DESI and subjective well-being, the second objective of sustainable development, $\mathrm{r}=.907, \mathrm{p}<.05$. In addition, there was a statistically significant, strong negative correlation between DIGI and the unemployment rate, the 8th objective of sustainable development, decent work and economic growth, $r$ $=-.963, \mathrm{p}<.01$. There were no statistically significant correlations between the DESI and other sustainable development measures taken into account in the case of Romania.

Although we have had important implications, there are some limitations to this research. As the methodologies for measuring the digitalization of nation and sustainable development are recent, the period considered in the analysis has been shortened. It would be appropriate to develop future research by analyzing a more representative set of countries, so that we can draw conclusions that may vary considerably when the rest of the world is included.

We shouldn't ignore the fact that the world is actually facing the worst public health and economic crisis of a century. The health problem affects all countries in Europe and North America including high-income nations. The required steps taken to respond to Covid-19's immediate threat, including the shutdown for weeks of many economic activities, have led to a global economic crisis with significant job losses and major impacts, especially on vulnerable groups. This is an important setback to the global ambition to achieve the SDGs, particularly for developing countries and population groups. It is, however, an established fact that digital communities appear to work better towards achieving sustainability objectives.

\section{REFERENCES}

1. Ababneh, T.A.M., Aga, M. The Impact of Sustainable Financial Data Governance, Political Connections, and Creative Accounting Practices on Organizational Outcomes. Sustainability, 11, 5676, (2019).

2. Ahi, P., Searcy, C., Jaber, M.Y., A quantitative approach for assessing sustainability performance of corporations. Ecol. Econ, 152, 336-346, (2018).

3. Bertini, P., Focus on technology hinders true digital transformation. Retrieved August 15, 2020, from https://www.brandknewmag.com/focus-on-technologyhinders-true-digital-transformation/ (2016).

4. Boros, A., Fogarassy, C., Relationship between Corporate Sustainability and Compliance with State-Owned Enterprises in Central-Europe: A Case Study from Hungary. Sustainability, 11(20), https://doi.org/10.3390/su11205653, (2019).

5. Boyd, D., Crawford, K., Critical questions for big data: provocations for a cultural, technological, and scholarly phenomenon. Inf Commun Soc, 15(5), 662-679, (2012).

6. Cantele, S., Zardini, A., Is sustainability a competitive advantage for small businesses? An empirical analysis of 
possible mediators in the sustainability-financial performance relationship. J. Clean Prod, 182, 166-176, (2018).

7. Clayton, T., Radcliffe, N., Sustainability: A Systems Approach. New York, NY, USA: Routledge, (2015)

8. Drexhage, J., Murphy, D., Sustainable development: From Brundtland to Rio 2012. Background paper prepared for consideration by the High-Level Panel on Global Sustainability at its first meeting 19 September 2010. Adv. Appl. Sociol., 5, 12, (2015).

9. Dang, G., Pheng, L. S., Theories of Economic Development. Infrastructure Investments in Developing Economies, Singapore: Springer, 11-26, doi: 10.1007/978981-287-248-7_2, (2015).

10. European Commission. (n.d.). The Digital Economy and Society Index (DESI). Retrieved July 30, 2020, from https://ec.europa.eu/digital-single-market/en/desi

11. Gijzen, H., Development: big data for a sustainable future. Nature, 502, 38-38, (2013).

12. Hampton, S.E., Strasser, C.A., Tewksbury, J.J., Gram, W.K., Budden, A.E., Batcheller, A.L. et al., Big data and the future of ecology. Front Ecol Environ, 11(3),156-162, (2013).

13. Hussain, N., Rigoni, U., Cavezzali, E., Does it pay to be sustainable? Looking inside the black box of the relationship between sustainability performance and financial performance. Corp. Soc. Responsib. Environ. Manag, 25, 1198-1211, (2018).

14. Jovanovic, M., Dlacic, J., Okanovic, M., Digitalization and Society's Sustainable Development - Measures and Implications. Zbornik Radova Ekonomskog Fakulteta u Rijeci / Proceedings of Rijeka School of Economics, 36, 905-928. 10.18045/zbefri.2018.2.905, (2018).

15. Nielsen, J., Intangible Assets, Sustainability And Value Creation. Retrieved October 20, 2019, from https://www.sustainablebusinesstoolkit.com/intangibleassets-sustainability-and-value-creation/, (2018).
16. Oprean-Stan, C., Stan, S., Brătian, V., Corporate Sustainability and Intangible Resources Binomial: New Proposal on Intangible Resources Recognition and Evaluation. Sustainability, 12(10), 4150, (2020).

17. Ordieres-Meré, J., Prieto Remón, T., Rubio, J., Digitalization: An Opportunity for Contributing to Sustainability From Knowledge Creation. Sustainability, 12, 1460, doi:10.3390/su12041460, (2020).

18. Schmarzo, B., What is Digital Transformation?, Retrieved August 8, 2020, from https://www.cio.com/article/3199030/what-is-digitaltransformation.html, (2017).

19. Schmidt, E., Cohen, J., The new digital age. Reshaping the future of people, nations and busines. Knopf, New York, (2013).

20. Schwab, K., The Fourth Industrial Revolution. Retrieved August 6, 2020, from https://www.weforum.org/about/thefourth-industrial-revolution-by-klaus-schwab, Geneva: World Economic Forum, (2016).

21. Shah, D.V., Cappella, J.N., Neuman, W.R., Big data, digital media, and computational social science possibilities and perils. Ann Am Acad Polit Soc Sci, 659(1), 6-13, (2015)

22. Sustainable Development Report. (n.d.). Sustainable Development Goals Index. Retrieved August 02, 2020, from https://www.sdgindex.org/about/

23. Tseng, M.-L., Lim, M.K., Wu, K.-J., Corporate sustainability performance improvement using an interrelationship hierarchical model approach. Bus. Strateg. Environ, 27, 1334-1346, (2018).

24. WCED (World Commission on Environment and Development) (1987) Report of the World Commission on Environment and Development: Our Common Future. Retrieved July 20, 2020, from https://sustainabledevelopment.un.org/content/documents/ 5987our-common-future.pdf 